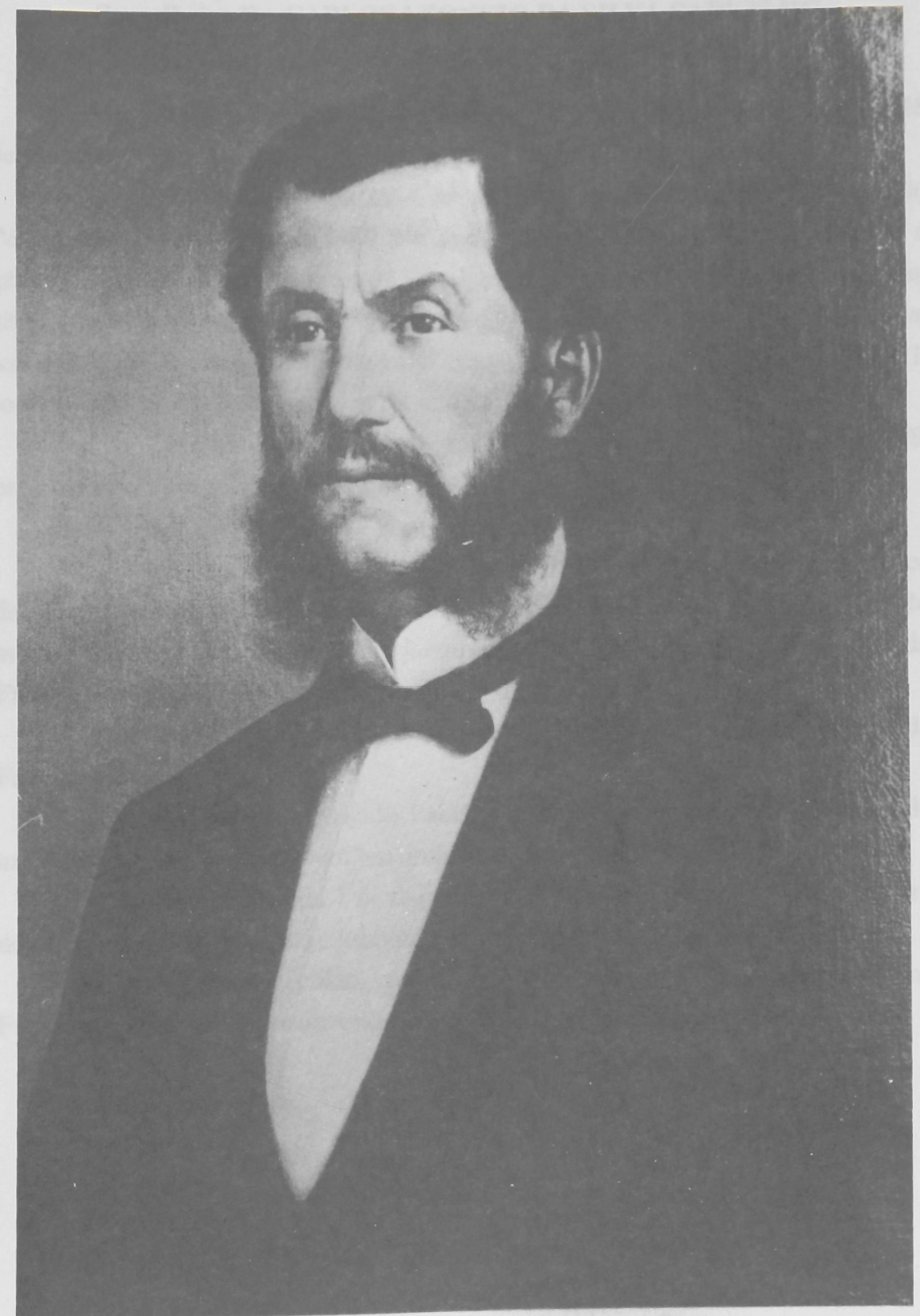

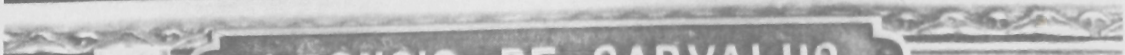
009 EE LNCIO DE CARVALHO 



\section{Conselheiro Dr. CARLOS LEONCIO DA SILVA CARVALHO}

(1890-1891)

Filho do Dr. Carlos Antonio de Carvalho, nasceu na Corte aos 18 de junho de 1847.

Matriculou-se, em 1864, no primeiro ano do Curso Jurídico de São Paulo, bacharelando-se em 1868. No ano seguinte defendeu teses e recebeu o grau de doutor. Foi aprovado por unanimidade. Inscreveu-se em concurso, em 1870, com Américo Brasiliense e José Joaquim de Almeida Reis. Classificado em terceiro lugar, foi nomeado lente substituto, por decreto de 4 de janeiro de 1871, tomando posse em 3 de fevereiro do ano seguinte.

Ocupou a pasta do Império no gabinete de 5 de janeiro de 1878, presidido pelo conselheiro Sinimbu.

De 1878 a 1880, foi deputado geral por São Paulo.

Por decreto de 7 de junho de 1881, foi nomeado lente catedrático de direito constitucional, das gentes e diplomacia. Tomou posse em 14 do mesmo mês. Por decreto de 31 de janeiro de 1885 foi nomeado bibliotecário da Faculdade de Direito, tomando posse em 4 de fevereiro.

Por decreto de 4 de outubro de 1890, foi nomeado diretor da Faculdade.

Fez parte do Senado Paulista e do Congresso Constituinte, sendo um dos relatores da primeira Constituição de São Paulo.

Por decreto de 7 de fevereiro de 1895, foi designado para a cadeira de direito público, na qual se jubilou, por decreto de 12 de janeiro de 1901.

Mudou-se, então, para o Rio de Janeiro, onde lecionou na Faculdade Livre de Direito e onde faleceu aos 9 de fevereiro de 1912. 